Chris Rowley, Saaidah Abdul-Rahman *

\title{
The Management of Human Resources in Malaysia: Locally-owned Companies and Multinational Companies ${ }^{* *}$
}

This paper is concerned with people management practices in companies in Malaysia. It examines the development of the main practice areas of the management of human resources (HR), the HR management (HRM) function and to what extent locallyowned companies (LOC) are influenced by multinational companies (MNC) operating in Malaysia. We found LOCs do not place a high priority on their HR practices and do not benchmark against the HR practices of MNCs. Overall, Malaysian people management generally would be better characterized as still more like 'personnel', than 'HR', management. Any acceptance and development of the HRM concept by Malaysian companies has been slow and cautious. This situation may prove problematic for future competitiveness and upgrading in the context of low wage cost competition from other countries.

Key words: Human Resource Management, Local Companies, Multinational Companies, Malaysia, Transfer

* Professor Chris Rowley, Faculty of Management, Cass Business School, City University, 106 Bunhill Row, London EC1Y 8TZ, UK, e-mail: c.rowley@city.ac.uk.

Saaidah Abdul-Rahman, Malaysia, e-mail: stvjb@yahoo.co.uk.

** Acknowledgements: Thanks to the British Academy, Committee for South East Asian Studies and the ESRC AIM (RES-331-27-0002) for grants that supported parts of this research.

Article received: February 15, 2007

Revised version accepted after double blind review: October 25, 2007. 


\section{Introduction}

The importance of human resources (HR) and their management remain critical to organisations and economies. Likewise, despite the emphasis often given to multinational companies (MNC), locally-owned companies (LOC) also retain their importance. For example, it is argued that HR management (HRM) is increasingly crucial for organisations (inter alia, Pfeffer 1994; Jackson/Schuler 2000; Barney 1991). HR can also contribute to the success of countries (Pieper 1990). Furthermore, HR are seen as the foremost intangible asset which composes a firm's core competence and crucial to solving organisational problems and increasing performance. Ultimately, organisational competitiveness is built upon HR it is argued. Furthermore, MNCs, as in Malaysia, have the benefit of drawing on foreign management 'software' (Smith 2000; 2003; Smith/Abdullah 2004) and practices, including in the HR area, from their head offices. Yet, despite this view of HRM's importance as a specialized business function and set of practices, it is a relatively new area of interest in Malaysia.

While the politics and economy of Malaysia is well covered, less is known about its people management. Some studies examined MNC influence on Malaysia as a host country, normally concentrating on economic development, foreign trade balances and employment creation, but with less focus on other aspects, including management practices, non-Japanese Asian MNCs and LOCs. Much of the extant literature mainly discusses HRM in foreign-owned firms and comparisons with local subsidiaries (see Abdullah 1994; Adnan/Ali 1990; Raduan 2002). One purpose of this paper is to examine the type of people management practices in Malaysia in both LOCs (domestic firms wholly-owned by Malaysians) and local plants of MNCs and the evolution and role of the HRM function and MNC influence. Our research questions concern to what extent HRM has found fertile ground to develop on relatively unchanged or is adapted to local social, cultural, political and legislative systems (see Rowley/Bae 2001; Rowley/Benson 2004 for examples), the development of the HR function locally and influence MNCs in these areas.

Our paper takes the following structure. Following this introduction we have main sections on the local background and context, the conceptual framework and methods. These are followed by sections of findings, discussions and implications and finally conclusions.

\section{Background and Context}

The management of HR and operation of LOCs and MNCs do not occur in a vacuum. The important background and context needs noting. Thus, we begin with a brief geo-political summary of the country. The federation of Malaysia was formed in 1963, a unification of four former British colonies - the Federation of Malaya (which gained independence from Britain in 1957), Singapore (which ceded in 1965), North Borneo and Sarawak. Malaysia is divided into two regions separated by the South China Sea. Peninsular Malaysia borders Thailand in the North and Singapore in the South. Sabah and Sarawak occupy one third of the island of Borneo, sharing common borders with Brunei and the Indonesian Kalimantan region. Malaysia consists of 13 states and the Federal Territory which comprises Kuala Lumpur (the federal capital), 
Putrajaya (the federal administrative headquarters) and Labuan (an island off the coast of Sabah designated an international offshore financial centre). In total, Malaysia covers 328,550 square kilometers (Ayudurai et al 2002; Rowley/Abdul-Rahman 2008a; 2008b).

Malaysia has an elected parliamentary system of government and constitutional monarchy with the King, the Federal Head of State, elected from among the nine Malay Sultans on a rotation basis for a five year term. Individual states have their own Sultans (hereditary) or Governors (citizens of distinction appointed for a specific period by the federal government) as heads and also state legislative assemblies. While the federal government decides on overall policies for finance, education, defence, development and other matters of national interest, state governments have exclusive control over access to, and use of, natural resources, such as land, water and minerals. Since the first elections in 1955 the federal government has been continuously ruled by the National Front coalition, consisting of mainly communally based political parties. The United Malays National Organisation (UMNO) plays the dominant role in the coalition government (Rowley/Abdul-Rahman 2008b).

\section{Economic}

Malaysia inherited a good basic physical infrastructure system, civil service (modeled on the British system) and primary export sector. Malaysia's post-colonial industrialization was highly dependent on state direction and foreign direct investment (FDI), resulting in economic growth and expansion of manufacturing. Economic success was partly due to a policy of attracting foreign-owned firms and MNCs to develop in a model of so-called 'export-oriented industrialization'.

Industrialization began with the pioneer industries programme in 1958, with the subsequent establishment of import substitution industries (ISI) producing manufactured goods from primary products, mainly tin, rubber and timber, as well as consumer goods, such as household detergents, toiletries and edible oil. The small domestic market was quickly satiated and from 1968 the government offered incentives to encourage production of manufactured goods for export markets and FDI.

However, ethnic-based political tensions in 1969 erupted in violent racial riots. This led to a new policy to restructure the economy and draw Malays into mainstream economic activities, pursued through the New Economic Policy (NEP) of 1971-90 (Second Malaysia Plan 1971). The policy included affirmative action for Malays (extended by the NEP's replacement, the 1990 National Development Plan, NDP).

In 1970 the laissez faire economic management of the 1960s was replaced by active government intervention. In the early 1970s export processing zones or Free Trade Zones (FTZ) were established, reinforced by the Industrial Coordination Act in 1975. FTZs were designed to attract FDI to export production sectors with incentives ie duty-free import of raw materials and capital equipment, tax concessions and infrastructure, all bolstered by the Promotion of Investment Act in 1986.

Malaysia embarked on the 'Look East' policy in 1982 and the 'Malaysia Incorporated' policy in 1983 (revived in 2005). These were attempts to emulate factors in Japan's economic success, seen as based on patriotism, discipline and work ethics, management systems and especially close cooperation between government and private 
sector. Simultaneously, the government attempted to shift the economy from labour intensive, agro-based and commodity intensive sectors towards capital intensive, high technology and service intensive industries through large-scale public investment, ie the 1985 Industrial Master Plan. This also meant giving higher priority to education and training and implementing HRM policies and strategies.

Economic growth was driven by exports, especially electronics which contributed significantly to manufacturing output and employment. Activities in the sector evolved from mere assembly of electrical components and household appliances of foreign brands (mainly import substitution fabrication) to higher value-added activities, including R\&D, design and marketing of 'local' brands for regional and global markets.

In response to the mid-1980s recession Malaysia revised its economic management philosophy. The public sector was downsized with greater emphasis given to the private sector. A privatization programme began. However, there remain issues such as companies that have state links and national prestige attached to them. The holding company, Khazanah, has approximately 40 partially owned state or 'governmentlinked' companies (GLCs), including Telekom Malaysia, SilTerra the microchip foundry, Rapid KL a transportation system operator, with bureaucratic origins as either former monopolists, such as the power firm Tenaga Nasional, or 'pet' government projects, such as Proton (Economist 2005). Under the national car programme the state invested heavily in Proton, founded in 1983 with Mitsubishi models and technology. This protected and heavily subsidised firm struggled to compete and has been in negotiations with foreign companies. An issue with these government-linked companies is that 'Political considerations often trump commercial ones...' and large scale redundancies are taboo (Economist 2005: 54). Another example is the crowded and fragmented palm oil sector (Malaysia is one of the world's largest producers with growing demand as a bio-fuel, generating a 23 percent price rise in just 2006 alone), with the idea (first mooted in 2003 but resisted because of possible job cuts) of merging the three state plantations controlled by PNB (the state-run investment equity fund) to form the world's biggest listed producer with market capitalisation of over US\$7 billion and sales of US\$2 billion (Burton 2006).

In 1990 came Malaysia’s Vision 2020 for further development. The desire was to create a more scientific and innovative economy. The policies and strategies for its first phase were set out in the Second Outline Perspective Plan 1991-2000. It embodied the NDP (which replaced the NEP), and contained several shifts in policy to provide new dimensions to development efforts to encourage more balanced development while maintaining the basic policies of the NEP to assist political stability and national unity could be ensured. The NDP placed greater emphasis than its predecessor on the goal of rapid industrialization and stressed the importance of HR development.

During 1986-97 rapid growth occurred, with the economy growing at an average annual rate of 8.5 percent, the longest period of sustained high growth in the country's history (Rowley/Abdul-Rahman 2008b). Although the 1997 Asian Financial Crisis ended the impressive economic growth, the economy had rebounded by 1999. Fiscal 
and monetary policies resulted in the economy recovering after a negative growth rate of -7.5 percent in 1998 (Ibid).

Economic development affected Malaysia's output and employment patterns. In the 1960s agriculture contributed more than one third of domestic output and accounted for more than half of employment, while more recently, manufacturing sector contributed one third of GDP, while the services sector, including government services, contributed more than one-half (Rowley/Abdul-Rahman 2008b).

By 2007 Malaysia had a labour force of 11.3 million (ILO 2007) and in 2005 its population were 16-64 years of age and just 4 percent 65 and over, with 11 million in employment (13 percent in agriculture, 36 percent in industry and 51 percent in services) and a low unemployment rate (3.5 percent) and a Gross Domestic Product per capita of US\$1,277 and growth of 5.6 percent, 3 percent inflation and US $\$ 4.7$ billion inward investment and US\$141.5 billion of exports (Rowley/Abdul-Rahman 2008a). While there is now greater competition with China for FDI, investors may disperse their capital in Asia due to risk diversification and with political and social stability, investment record, infrastructure and a skilled workforce, Malaysia remains an attractive locale for FDI into Asia.

\section{Social/cultural}

Malaysia is a multi-ethnic, multi-cultural and multi-religious society with a diversity of languages. (Ayudurai et al 2002; Rowley/Abdul-Rahman 2008a; 2008b). In 2005 the 26.1 million population comprised: 65.1 percent Bumiputera (a Malay word literally meaning 'sons of the soil' and is used to refer to Malays and other indigenous ethnic groups of the Peninsular, Sabah and Sarawak) 26.0 percent Chinese, 7.7 percent Indians and 1.2 percent others (numerous small groups).

The Malays are Muslims and Islam is the official religion of the country and the Malay language is the official language. The Chinese are mostly Buddhist and the Indians are largely Hindus. A very small percentage term themselves 'Eurasians', descendants of Portuguese, Dutch and British colonizers from the $16^{\text {th }}$ century. The Eurasians and indigenous ethnic groups in Sabah and Sarawak are mainly Christians (Rowley/Abdul-Rahman 2008b).

This diversity was the result of British colonial economic activities, expansion and immigration policies. Tin mining and rubber cultivation relied on labour from outside, namely China and India, while the Malays were not incorporated directly into the economic system. This produced stratification of ethnic groups according to occupations. Thus, the Malays were engaged primarily in the subsistence economy, cultivating mainly rice and some rubber in rural areas; the Chinese were active in commerce and business, especially in urban areas; while the Indians formed the wage labour class in rubber and oil-palm plantations. Each group experienced particular socio-economic disadvantages: the Chinese had economic power, unlike the Malays, who had political power (Mellahi/Wood 2004). This has important implications for HRM as the need to maintain a satisfactory relationship between the ethnic groups dominated political, economic and social policies (Mellahi/Wood 2004; Rowley/Bhopal 2002; 2005a; 2005b; 2006). 
Therefore, the social and cultural impacts on Malaysian management include the following (Mellahi/Wood 2004). Malaysian management practices should be understood in the context of this mixture of local Confucian, Islamic and Western values (Mansor and Ali 1998). Malaysia is a collectivist society, for example, social relations, self sacrifice and family integrity are very strong (Noordin et al 2002). Hofstede (1991) noted that in Malaysia high power distance was reflected in unwillingness to make decisions without reference to the most senior executive, a high ratio of supervisory to non-supervisory personnel, strong uncertainty avoidance and low individualism.

Indeed, Malay culture is essentially a cooperative society based on 'kampong' (village) and 'gotong royong' (mutual help) values (Taib/Ismail 1982). Importantly, 'The gotong royong is underpinned by the Islamic concept of the ummah (Islamic religious community) where each muslim is responsible for fellow muslims' (Mellahi/Wood 2004: 202). Concepts of Islamic work ethics and work values have origins in the Quram (Alhabshi/Ghazali 1994). Others note that such ethics advocate work to give meaning to life and economic activity is an obligation, with dedication to work a virtue and an emphasis on cooperation and consultation (Darwish 2000). Malay culture strongly emphases the importance of having and maintaining 'face'. Furthermore, Islamic values and teaching strongly emphasize obedience to leaders. Therefore: 'The authority of the leader and manager is thus accepted as right and proper and subordinates are expected to show respect and obedience to superiors' (Mellahi and Wood 2004: 208). However, some argue there is 'dynamic followership' (Beekun/Badawi 1999), with onus on leaders to convince subordinates orders are worth obeying rather than just imposing them. So, leaders should consult before making decisions. Also, there is an emphasis on forgiveness, kindheartedness and compassion, harmony, cooperation and conflict avoidance while leaders, in turn, are expected to take responsibility for employees' quality of working life and show concern for their families and society (Mellahi/Wood 2004). Thus, Malays are '...socialized to be non-assertive and compliant, and humility, courtesy and tactfulness are strongly held values. The latter have a strong impact on HRM policies and practices.' (Mellahi/Wood 2004: 208). For example, Malay values make direct discipline at work unacceptable because it leads to a loss of face.

Chinese Malaysian cultural values are to a large extent similar to Malay ones, for example, collectivist and high power distance. However, 'The sharp difference between the two values is entrepreneurial drive' (Mellahi/Wood 2004: 210), which has strong traditions in the Chinese.

Thus, in general, indigenous Malaysian management was a composite. The influence of the former British colonial powers was joined in the 1970s with some Americanization of organisations due to US dominance of the management science field and aid in the form of training, for example, via the Ford Foundation. The 1980s 'Look East Policy' introduced ideas Japanese management practices and values to the mix. Therefore, the business environment has shifted management culture slightly from more collectivist towards more individualist practices, leading to some erosion of older HR practices (Mellahi/Wood 2004: 209). For example, there were attempts, especially by foreign MNCs, to Westernize HRM. However, it remains that: 'Overall Malaysian companies pick and mix Japanese and Western HRM practices to suit their 
needs.' (Mellahi/Wood 2004: 210). Indeed, within this milieu of cultural and values pluralism people management '...continues to exhibit a number of distinctive features' (Mellahi/Wood 2004: 201) including targeted affirmative action policies, paternalism at both government and firm level and government efforts to promote selected sectors. Also, 'A range of authority mechanisms prevail at community, national and international level, strongly shaping economic and social outcomes...' (Mellahi/Wood 2004: 210) including in HRM.

\section{MNCs in Malaysia}

There is research on MNCs and HRM, especially between developed economies (see, inter alia, Tayeb 1998). There is less on Asian MNC operations in other Asian economies. Research on the influence of MNCs on the management of Malaysia's domestic firms is patchy, with most work focusing more on the impact on the economy. For example, Rasiah (1988) and Ali (1992) noted MNC influence on the economy in terms of manufacturing output, exports, employment and technology transfer. Adnan and Ali (1990) stressed the lack of MNC commitment to allocate funds for research and development in host countries, more often carried out by parent companies, depriving host countries of opportunities to enhance domestic innovative ability.

The more MNC and HRM-related work includes the following. Abdullah (1994) examined MNC employment absorption, human capital formation and technological change, finding influences in promoting employment, training and innovation, with much more proactive policies towards HRD than local firms. Kuruvilla (1996) distinguished between HR practices in 'import substitution industrialization' (ISI) and 'export oriented industrialization' (EOI) strategies. Generally, 'new' HR systems were more likely in the EOI sector as it was typically dominated by FDI and diffusion of HRM from investor countries reached them quicker. Smith and Abdullah (2004) examined more recent changes in Malaysian HRM. Bhopal and Todd (2002) and Wad (2001) focused on trade unions and industrial relations (IR); while Bhopal and Rowley (2002) examined how government concessions to labour and unions were being undermined by capital and MNCs. Rowley and Bhopal (2005; 2006) looked ethnicity and MNCs.

There is also some limited work on the transferability of MNC parent-country HRM practices to Malaysian subsidiaries. For example, Wolfe and Arnold (1994) on U.S. and Japanese firms. Some studies assessed the impact of Japanese-style management and FDI. For instance, Hooi (2002) examined promotion practices in Malaysian enterprises, concluding they, including those with Japanese interests, had not designed practices after those of Japanese enterprises. Thome and McAuley (1992) reported that Malaysian managers complained about promotion ceilings, poor communications and a lack of delegation from Japanese managers to local offices. Raduan (2002) examined the transferability of Japanese HRM to subsidiaries, particularly employment practices, remuneration systems, career development, management strategies and workplace industrial relations practices. It suggested that Japanese-style HRM in Malaysian subsidiaries was either present to a limited degree or completely absent. The purpose of HRM was seen as a form of labour control, as long as production proliferated and companies could sustain their profits. 


\section{People Management in Malaysia}

From the time when Malaysia gained its independence from Britain (in 1957), the wider aspects of human behaviour were a neglected issue in organisations, with narrow concentration mainly on work simplification and methods for increasing output. Even in the 1970s employers still gave a low priority to personnel issues, with the function often operating only as a sub-unit of 'General Affairs' departments. At that time government policies focused on economic development, poverty reduction and ethnic integration. For instance, in 1970 the New Economic Policy (NEP) was introduced with the two main objectives of the eradication of poverty and restructuring of society and elimination of the identification of race with major economic functions. Programmes included infrastructure development, education expansion, employment creation in the MNC export-oriented industries, encouragement of more Malay entrepreneurs and professional and managerial expertise in administration, science and technology.

It was not until the 1990s that some management and organisations began to reassess their corporate philosophy in favour of regarding people not as 'costs' but as 'assets', one of the key underpinnings of HRM. Some Malaysian managers began to realize that the management of HR could help bring about organisational stability and harmony. Indeed, the ethnic diversity of the Malaysian workforce required appropriate HRM solutions (see Rowley/Bhopal 2005).

Not only had some companies begun to recognise the increasing importance of HRM, but so had the state. It recognized the importance of developing human capital. For instance, policies stressed HR development (HRD). Therefore, one response to the need to continually upgrade the workforce was the HRD Act (1992), which initiated the HRD Council (HRDC), to coordinate and develop HRD programmes, especially for the private sector. The HRDC administers the HRD Fund (HRDF). Employers in manufacturing and services sectors register with the HRDC and contribute monthly levies equivalent to one percent of their wage bills (Ragayah et al. 2002). The HDCF reimburses part of the costs of approved training, retraining and skills upgrading programmes undertaken by employers. Such investments in employee development are often taken as integral to HRM and recognition of HR as 'assets' to be invested in, not costs to be reduced.

\section{Conceptual Framework}

This framework is outlined in Figure 1. This has several key aspects, as explained below.

\section{HRM Function and Practice}

The antecedence of the management of HR in organisations includes the personnel management (PM) function (Rowley 2003). HRM is primarily North American in origin and development (Beer et al. 1984; Fombrun et al. 1984). Despite HRM's widespread use as a term, definitions remain diverse, encapsulating various meanings (Storey 1992; Storey/Sisson 1993; Rowley 2003). HRM can simply be just another term for PM or even what 'good' PM should be. Alternatively, HRM can refer to a more business-oriented and integrated approach to the management of $\mathrm{HR}$, with the way an 
organisation manages its workforce matching its strategy. Indeed, Legge (1989) contends that HRM is distinctive in at least three ways. First, PM focuses more on the management and control of subordinates, whereas HRM also encompasses the management team. Second, line managers play a key role in HRM, unlike in PM. Third, the management of organisational culture is an important aspect of HRM, but not PM. Accordingly, it is argued that HRM is a more centrally strategic task than PM. Others (e.g. Poole 1990; Storey 1992) also consider the linking of HR practices to the strategic aims of the business as the core feature that distinguishes HRM from PM. Thus, a main distinction of HRM is its perceived integrated and strategic elements.

Figure 1: Conceptual framework

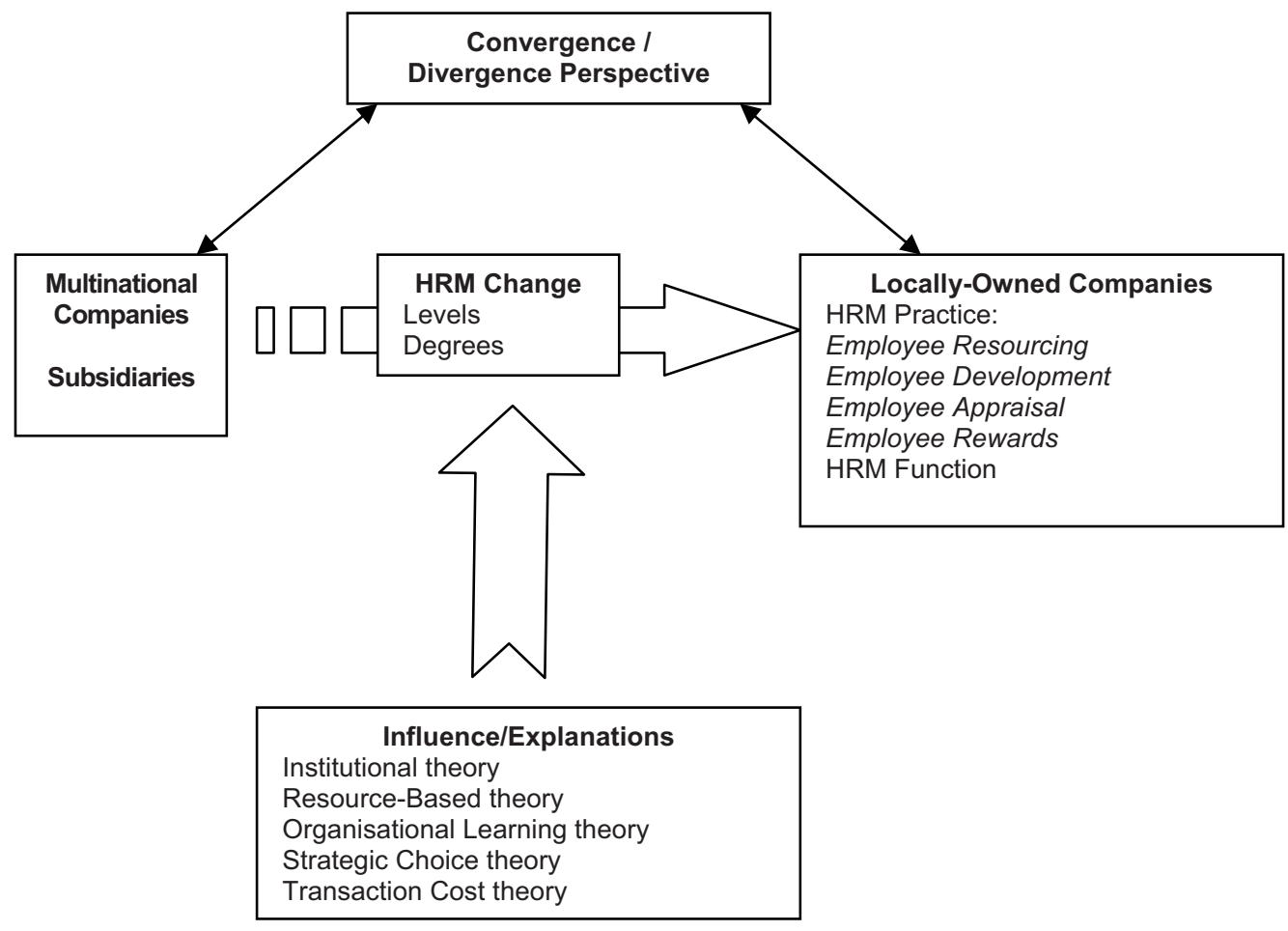

The scope of HRM also varies. In general, HRM's main functions are seen as including procurement, development, evaluation, compensation and separation (Flippo 1980; Shin 1999). For instance, Walton and Lawrence (1985) identified four major areas: reward systems (including compensation and benefits); influence mechanisms (i.e. participation, job design and work organization); selection; and development. Schuler's (1989) 'HRM Practice Menu' had: planning, staffing, appraisal, remuneration, training and development and labour-management relations. Rowley (2003) included the common practice categories of: employee resourcing (how organisations staff their operations, i.e. recruitment and selection); employee development (how organisations develop their staff, i.e. training); employee appraisal (how organisations monitor staff performance, ie appraisals) and employee rewards (how organisations 
remunerate their staff, i.e. pay and benefits). We use these four broad practice areas for our study. Additionally, we look at to what extent LOCs companies emulate the HRM of MNCs operating in Malaysia.

\section{Influence/Explanations of HRM Change}

Various theoretical viewpoints can help caste light on people management, developments and MNC transfer issues (some developed from Rowley and Bae 2004). These indicative perspectives below contribute to an over-arching theoretical debate about possible coming convergence or continuing distinctiveness, or even divergence, in management practices, including HRM. This convergence perspective, now renewed and given a modern twist by globalization (see Rowley/Benson 2004), argues that due to the spread of several factors (i.e. economic development, industrialization, technology), economies become increasingly similar (Kerr, et al. 1959). An implication of this is that the HRM systems of countries will also grow more alike, leading to greater similarities in practice. However, others argue that there may be a range of contingent impediments (i.e. cultural and institutional differences) between economies that in turn limit change and convergence. Indeed, even more variegated HRM may be encouraged.

What might impact on people management and its change? There are several possible theoretical viewpoints, including the following.

\section{Institutional Theory}

This suggests firms may adopt HR practices not because of 'effectiveness' but due to specific social forces, such as 'constraining', 'cloning' and 'learning' factors (McKinley et al. 1995). Constraining factors could shift as HRM becomes interpreted more positively and gains legitimacy. This movement in social constraints subsequently encourages firms to conform to legitimate structures. Cloning forces pressurize firms to mimic the actions of leading companies in the sector. Learning forces are shaped through learning processes taking place in educational institutions and professional associations. All these three social forces together push firms to adopt institutional rules which could include HRM systems. Thus, there could be mimetic isomorphism (Meyer and Rowan 1977), the copying of HRM. Using this theory Malaysian management and firms could take up HRM due to mimetic isomorphism.

What might be one possible reason for more positive views of HRM? ResourceBased Theory can help shed light on this.

\section{Resource-Based Theory}

This emphasizes the significance of internal company resources. Resources that are valuable, rare, inimitable and non-transferrable become core competencies, which generate competitive advantage for firms (Barney 1991; Wernerfelt 1984). Among various resources, $\mathrm{HR}$ are gaining significance as their management can generate stronger imitation barriers compared to other resources. Also, firms may realise that human assets are more important in the knowledge-based economy. Efforts by firms to attract and retain HR can be explained by this view. In the past many firms paid little attention to HR retention, but now many have a higher level concern regarding HRM values with top management perceptions of the value of HR for gaining com- 
petitive advantage. Thus, Malaysian management and firms may take up HRM as they increasingly come to recognise the growing significance and importance of the management of HRs as key internal resources.

What might be a way Resource-Based Theory is absorbed? Organisational Learning Theory is one possible route.

\section{Organisational Learning Theory}

This can be conceived of as 'the process of creating, transferring and institutionalising knowledge that drives organizational adaptation' (Snell et al. 1996). 'Knowledge' has been increasingly regarded as a critical source for national and organisational competitiveness. Indeed, some firms have established knowledge management systems to stimulate knowledge creation and sharing (i.e. creating new positions, such as Chief Knowledge Officers) and launched corporate venturing programmes to enhance knowledge creation initiated by 'intrapreneurs' (entrepreneurs within companies). Given this, Malaysian management and firms could increasingly take up HRM due to the transfer and institutionalisation of knowledge via organisational learning.

What might be a way Organisational Learning Theory develops? Strategic Choice is a possibility.

\section{Strategic Choice}

Here firms proactively make choices of certain HRM systems. The strategic management of HRs suggests that 'fit', both 'internal' (i.e. the extent of alignment among the HRM system as a whole) and 'external' (i.e. the alignment among the HRM system, business strategy and other organisational architectures, such as culture and structure), improve organisational performance. With internal fit the rationale is that 'bundles', rather than individual, HRM practices, are better for firm performance (MacDuffie 1995). For external fit, studies focused more on the linkage between generic business strategy types and HRM system types. ${ }^{1}$ With this theory Malaysian management and firms could come to take up certain types of HRM as a strategic choice that fits their situation internally and externally.

How is Strategic Choice influenced or made? One influence is via Transaction Cost Theory.

\section{Transaction Cost Theory}

This can be taken as viewing market transaction and internal production/development of HRs as alternatives. There are costs associated with both arrangements for managing HR: transaction costs in market arrangements and bureaucratic costs in hierarchical arrangements (Lepak/Snell 1999; Williamson 1975). Therefore, choices in HR practices, such as long-term attachment versus flexibility, depend upon the relative

1 For example, Bird and Beechler (1994) associated Miles and Snow's (1984) generic strategies with Schuler's (1989) HRM patterns (i.e. defender-accumulation, analyzer-facilitation, prospector-utilization). Arthur (1992) found that Porter's (1980) cost advantage strategy was highly related to a cost-reduction HRM type and differentiation was associated with a commitment-maximization HRM system. Basically, these studies assumed that business strategy was a critical factor for the choice of HRM system. 
costs associated with each arrangement for managing HR. For instance, firms may have inflexible labour markets, and hence keep more long-term employment practices regardless of bureaucratic costs incurred by hierarchical arrangements due to issues such as difficulties in monitoring and securing compliance from workers. Thus, the development of flexible type HR practices may be impacted on. Therefore, Malaysian management and firms could take-up certain types of HRM due to the differential costs involved.

In sum, a range of theoretical perspectives can help explain Malaysia HRM. MNCs play varied roles within these as creators and carriers of HRM. At the same time, some pressures may operate independently of MNCs.

Another important conceptual point needs to be made. Of course, HRM changes can occur in several dimensions, such as levels and degrees of acceptance. First, levels and acceptance (see Bae/Rowley 2001; Rowley/Benson 2002) of change in HRM. One way of viewing levels of change is to use the concept of HRM system structure (Becker/Gerhart 1996). The HRM system can be conceived as a triple-layered structure: (1) 'architecture' (or 'deep structure'); (2) policies; (3) practices. Architecture is the basic principles and assumptions underpinning the HRM system. Policies are the guiding principles of HRM. Practices are the day to day schemes giving force to the policy-mix. Change at one level does not necessarily imply change at the other levels. For example, workplace resistance may mean formal policies become unworkable. Thus, Malaysian management and firms may display HRM practices at different levels, not necessarily by at of them.

Simultaneously, within these different levels there is a degree to acceptance of HRM practices and changes. Resistance to change (i.e. in employees or the management cadre) may mean that policies become unacceptable or formally in situ but unused or not used in the manner envisaged. This is linked to the concept of 'institutionalization' (Kostova 1999). This requires not just 'implementation', whereby formal rules are followed; but additionally 'internalization', with commitment to, satisfaction with and psychological ownership of, practices. A range of options then produces a spectrum from mixed to 'assent', 'ceremonial' and 'active' take-up. Given this, Malaysian management and firms can display variation in degrees of acceptance of HRM.

One benefit of recalling such classifications is that they allow moves from simple, stark 'yes' or 'no' answers, with more nuance, calibration and simultaneous 'yes' and 'no' answers, with change at some levels, yet not necessarily at others and degrees of acceptance. This provides a useful lens through which to view developments in HRM, allowing more subtle and disaggregated analysis. These frameworks can be borne in mind when viewing developments in HRM. Detailed use further than this is beyond the scope of this paper, but can be a tool for future work.

\section{Research Methods}

This research utilizes a case study approach. We will not rehash and repeat the wellworn debates about the advantages and disadvantages of different types of research methods, use of cases, etc here, other than to note we are aware of them. The domestic firms were wholly owned by Malaysians and had at least 50 full-time employees. 
Firms were selected randomly from membership lists of the Federation of Malaysia Manufacturers and the National Chamber of Commerce. Some 60 firms were approached via telephone calls. In almost all cases the researchers were then instructed by the person who answered the telephone to write a formal letter, requesting an appointment. This type of bureaucratic behaviour is very common among Malaysian organisations. However, several firms did not subsequently respond to the written request. After several follow-up telephone calls, 11 firms granted research access. This sort of response and level is indicative of research in the area and country.

The firms were all located in the vicinity of the Kuala Lumpur (the capital city) region of Malaysia. The firms were in the main new and emerging, established post1970, averaging between 5 and 23 years old. Table 1 provides a summary of their employment and products. Employment size ranged from 90 to 320, with an average of just over 200. In many countries and definitions these would be seen as 'small firms' or perhaps 'small and medium sized enterprises'. Products varied from textiles, rubber and plastics and paper and stationary to cosmetics, food and beverage and household products.

Table 1: Domestic firms products manufactured and size

\begin{tabular}{l|l|c|c}
\hline Categories & Products & Employees & Firm \\
\hline \multirow{2}{*}{ Textile and garment } & Knitted garments, dresses, clothing for infants & 245 & 1 \\
\cline { 2 - 4 } & Textiles (dyed and printed) & 90 & 2 \\
\hline \multirow{3}{*}{ Food and beverages } & Dairy health drinks, yoghurt, desserts & 250 & 3 \\
\cline { 2 - 4 } & Grain mill products, spices & 320 & 4 \\
\cline { 2 - 4 } & Food ingredients, curry powder, soup & 300 & 5 \\
\hline \multirow{2}{*}{ Cosmetics } & Colour Cosmetics, Skin Care Products & 140 & 6 \\
\cline { 2 - 4 } & Cosmetics, toiletries, personal care products & 170 & 7 \\
\hline \multirow{2}{*}{ Household products } & Gloves (for domestic and industrial use) & 170 & 8 \\
\cline { 2 - 4 } & Fibreglass water tanks & 120 & 9 \\
\hline Rubber and plastic & Feeding bottles for infants & 250 & 10 \\
\hline Paper and stationery & Bags, labels and cups & 180 & 11 \\
\hline
\end{tabular}

The data were primarily drawn from field interviews. Information regarding HR practices and other constructs, like company characteristics, were recorded in a simple questionnaire format. However, some respondents preferred to answer some questions only, thus leaving gaps in information. The semi-structured interviews were conducted in 2004. There were approximately 1-2 interviews per firm, totaling 20 interviews. Each interview lasted approximately 60 minutes. The respondents were managers or management personnel in control of the company's HR. All the companies requested confidentiality and anonymity as a condition of participation, and accordingly individual names are not disclosed.

This research was supplemented by a case study of a large MNC (South Korean) operating in Malaysia. This subsidiary was set up in Malaysia in the 1990s and produced and assembled a variety of electrical and electronic components and products, predominantly microwave ovens and related items, both for its own and other MNC assembly. Some 60 percent of this plant's sales were in North America, with just 10 percent locally in Asia. The plant had 385 staff (197 employees and 188 'non-regular 
employees' or contract workers), some 80 percent of which were in production. The workforce was approximately 61 percent Malay, 4 percent Chinese, 3 percent Indian, and also 22 percent Indonesian and 7 percent Nepalese.

The MNC case study involved factory and office tours and 30 semi-structured interviews with all levels of people. These included Korean senior management, Malaysian managers and a variety of workers as well as experts in the area. There were also interviews with key HR managers in the corporate Head Office in Korea. This data was collected in 2004. Company records and documents were also used.

\section{Findings}

In the following section we discuss our research findings. This is analytically organized via the main HRM practices of employee resourcing, employee development, employee appraisal and employee rewards in both LOCs and MNCs. The structure and main findings are summarized in Table 2.

Table 2: HRM in contrasting indigenous domestic and multinational firms

\begin{tabular}{|c|c|c|}
\hline Aspect & \multicolumn{2}{|c|}{ Main Findings } \\
\hline HRM Practice & LOC & MNC \\
\hline $\begin{array}{l}\text { Employee } \\
\text { Resouring }\end{array}$ & $\begin{array}{l}\text { Reliance on external labour market to fill vacancies } \\
\text { Simple procedures } \\
\text { Performed whenever vacancies arise } \\
\text { Preference for foreign workers }\end{array}$ & $\begin{array}{l}\text { Reliance on external labour market to fill vacancies } \\
\text { Tight local labour market } \\
\text { Long term use of foreign, contract labour } \\
\text { Ethnic segmentation of employment }\end{array}$ \\
\hline $\begin{array}{l}\text { Employee } \\
\text { Development }\end{array}$ & $\begin{array}{l}\text { No induction } \\
\text { On-the-job, task-related or familiarization training } \\
\text { Low priority in allocation of training budget }\end{array}$ & $\begin{array}{l}\text { Sophisticated induction } \\
\text { On-the-job, in-house } \\
\text { Training important but hindered by labour turnover }\end{array}$ \\
\hline $\begin{array}{l}\text { Employee } \\
\text { Appraisal }\end{array}$ & $\begin{array}{l}\text { Assessment of personality and behaviour } \\
\text { Judgmental (as opposed to developmental) }\end{array}$ & 'One-way' \\
\hline $\begin{array}{l}\text { Employee Re- } \\
\text { wards }\end{array}$ & $\begin{array}{l}\text { Two-tier system: monthly salary (white-collar); daily } \\
\text { rates (blue-collar) workers } \\
\text { Benefits based on requirements of labour laws }\end{array}$ & $\begin{array}{l}\text { Benchmarking other MNCs } \\
\text { Wide range of benefits }\end{array}$ \\
\hline HR Function & $\begin{array}{l}\text { Absence of HR managers } \\
\text { Maintenance and regulation of employees } \\
\text { Autocratic management/top-down communications } \\
\text { Traditional PM }\end{array}$ & $\begin{array}{l}\text { Well developed and resourced } \\
\text { HRs seen as important to business } \\
\text { Autocratic management/top-down communications } \\
\text { HRM approach }\end{array}$ \\
\hline MNC Influence & $\begin{array}{l}\text { Recognition different, higher standards } \\
\text { Seen as costly to adopt MNC standards } \\
\text { Low priority given to benchmarking MNCs }\end{array}$ & $\begin{array}{l}\text { No links to local domestic firms } \\
\text { Locals not competitors as 'poorer' employers } \\
\text { Influence from other MNCs }\end{array}$ \\
\hline
\end{tabular}

\section{Employee Resourcing}

Firms can use a range of sources and labour markets, from internal to external (ranging from local to national to international). As one local manger put it, firms had to rely on sources external to the firm to fill vacancies in the skilled and highly-skilled categories. This implies that firms were not generating their own skilled workers adequately, or that it was cheaper and faster to obtain them from outside the firm. There 
were limited promotion opportunities and a lack of job rotation for employee motivation and production flexibility in the cases.

Production workers typically made up a very large proportion (averaging 75-80 percent) of the workforce. Also, many respondents agreed with the admission that production labour turnover was extremely high. Thus, these workers were recruited all year long. The recruitment process was simple and informal. Local companies relied on employee recommendations and also targeted school leavers.

Furthermore, "We use foreign workers" was a common comment. Firms tended to utilize foreign labour under the terms and conditions of Malaysia's Policy on the Employment of Foreign Workers (1992). These workers, who came mainly from Bangladesh, Nepal, Vietnam and Cambodia, were allowed to work only for a specified period (two years), after which extension requests had to be made to the Immigration Department.

Recruitment was also influenced by ethnicity. Malaysia has positive discrimination and quotas. Local workers were largely Malays, but from the rural areas. Foreign workers were recruited in groups according to their nationalities. As one manager put it: it was easier to control such workers, not least as they were not allowed to job-hop. Additionally, this company preferred to recruit from Nepal due to their worker's ability to converse in English. Given the many different languages in use by the management and workforce, the need for a common way to communicate was critical. Also, this manager stated that personal links and ethnic groupings could improve teamwork.

The MNC had some similar employee resourcing practices. The labour market strategy of using migrant workers was described as: "Involving local contractors to get them" (interview notes). On closer questioning this was operating in a way reminiscent of a 'gang system' and combined with ethnic stratification of the workforce. The HR team dealt with contractors to supply specified labour, which did not then work for the MNC itself, but rather the contractor. Additionally, members of the HR team regularly went to 'supplier' countries personally, a process justified as: "We can then see what sorts of people we are going to be sent and make the first cut" (interview notes). However, there was then the problem of 'responsibilities' as often management had to manage via the contractor rather than directly.

The MNC also suffered high labour turnover rates. According to a member of the HR team: "This problem was especially widespread in the most unpleasant production jobs, those that are physical and in hot areas of the factory" (interview notes). These were the classic '3D' - 'difficult, dirty and dangerous' - jobs. It was also argued that: "Local Malay workers were reluctant to undertake these jobs" (interview notes), with the argument being made that the tight labour market allowed them to simply leave. Therefore, there was extra pressure to import, as one manager put it: "...more suitable labour" (interview notes). Often areas of production and work were ethnically and gender segmented. For instance, during visits around the factory's production lines a stark contrast was noted. On the one hand, the hot and heavy spraying jobs were done only by Nepalese males. On the other hand, the moving assembly lines for electronic component assembly were mostly staffed by young (averaging 21 years old) Indonesian females. It was confirmed by a manager that: "Of course, all these foreign 
workers were on fixed contracts" (interview notes). He went on: "That's good in some respects as these jobs can soon exhaust people, but bad in other ways as there are some good workers we'd like to keep and develop for promotion, and so on, but they have to leave" (interview notes). We explore this further in the next section.

\section{Employee Development}

Of the LOCs, only three professed to have some training budget, although even for these firms no monetary figures were revealed or forthcoming. Skill-formation among workers occurred on site, mainly in the form of on-the-job, task-related training and work familiarization programmes. This type of training was, it was argued, cheap and effective and very much relevant to the requirements of the firms. It was commonly argued that the main drawbacks were: first, the level of skill transfer was limited by the expertise of the trainers; second, inefficient techniques and processes were transmitted; and third, it afforded little opportunity for innovation. Management had little or no expectations for staff to continuously acquire knowledge about new technology, while on the other hand employees appeared not to regard competence-building as an individual requirement that they had to fulfill in order to progress.

For the most part employee development in the LOCs was in terms of technical knowledge and skill training. Little or no emphasis was given to social and intercultural skills and competence development, even though Malaysia was a culturally diverse operating environment, exacerbated by the employment of migrant workers of various other Asian nationalities. As a matter of fact there were no formal induction programmes for new staff. It was usual for newcomers to learn about the company's structure and goals only through socialization with their workmates. This socialization process also acted as a learning process through which newcomers' attitudes and behaviour was shaped to help them fit into the work environment.

The LOCs, overall, only provided workers with basic training. There was an absence of career development planning. The majority of the companies did not attend to the competence needs of all their employees. Management in the smaller companies in particular argued that they could not afford 'expensive' educational investments, while larger firms tended to focus on core members of staff only it was asserted by management. Thus, job-hopping was a trend among local workers. In order to address the high turn-over of production line workers, management turned to hiring foreign workers for fixed periods, as noted above.

The MNC was simultaneously both similar and different in various areas of employee development to the LOCs. The training methods were in much the same pattern, i.e. in-house and on-the-job. Nevertheless, new workers were put on a separate assembly line that was kept exclusively for fresh staff and it was explained that: "These people were only put into the other lines once they had been trained-up" (interview notes). Additionally, "An induction programme and socialization are taken very seriously" (interview notes) by management. This could be seen in various aspects of operation, such as the singing of the company song (which was printed in the employee handbook handed out to all staff on joining the company), and showing of corporate information and 'success' videos in the canteen and throughout the factory, and so on and a single status canteen. However, there was a de facto distinction here as it had two 
lines: one serving Korean food that all the Koreans frequented and another one for other foods that the rest of the workforce used.

The MNC was also reliant on large numbers of foreign workers on fixed term contracts. While on the one hand this employment practice helped overcome the tightness of the local labour market, it also brought its own management issues, as noted in the earlier section. This was in terms of being able to forge a cohort of people suitable for internal promotion. Thus, one problem with reliance on fixed term contact foreign workers is that for management such staff: "They were often not suitable for internal promotion or career development as they will eventually have to leave the country" (interview notes). At the same time the opposite side of the coin was that: "So there is a constant need for us to keep retraining the fresh contractors" (interview notes). This phenomenon bedeviled the MNC and undermined its management's stated aim of developing and promoting indigenous talent and managers in a stronger internal labour market.

Our findings here do not contrast greatly with some earlier findings (Abdullah 1994) that while locally owned Malaysian manufacturing enterprises emphasised human capital formation, MNCs had a greater incidence of training and retraining of their workforce. The most important aspect of MNC training consisted not only of training provided to production workers, but also to skilled workers and management staff geared towards complementing existing skills.

\section{Employee Appraisal}

In general, performance appraisals were conducted according to simple procedures in the LOCs. The evaluation criteria utilized were broad, rather unspecified standards connected to the job performed and personal behaviour and characteristics, i.e. pleasantness and compliance. Most commonly appraisals took place annually, usually on the anniversary of appointment, with immediate superiors responsible for their conduct. As appraisals were often largely based on subjective assessments of personality and behaviour, results were judgmental rather than developmental. There were no appraisal discussions or mentoring between managers and their staff. Furthermore, there was the cultural complexity of workers who were afraid to disagree with supervisors and managers in case they were regarded as rude and showing a lack of respect for their superiors. This situation reflects Malaysian cultural values, which, regardless of ethnic identity, places emphasis on harmony, respect for elders, acceptance of hierarchy and focus on the group over the individual (Asma 2001, also see Farh et al. 1991).

Actually, in two LOCs it was mentioned that the appraisal system should be a process involving frank discussion which included an element of critique. However, in Malaysia appraisals generally have a negative connotation and are regarded as threatening. Indeed, as Hofstede (1998: 18) pointed out, the use of appraisals in collectivist countries: "destroys the harmony which is expected to govern interpersonal relationships. It may cause irreparable damage to the employee's face and ruin his or her loyalty to the organization". Therefore, appraisals had to be handled with considerate sensitivity in a culture where people were reluctant to be open and direct in encounters. 
At the same time, however, it was argued by many LOCs that local workers lacked a positive attitude towards discipline, attendance, time-keeping and punctuality. Consequently, the two LOCs had a preference for foreign workers from the Indian sub-continent and Vietnam as they believed that these workers complied rather more easily compared with local workers.

The MNC had similar issues to the LOCs, partly due to ethnic segmentation. This gave rise to some underlying tensions in the MNC subsidiary. For instance, its emphasis on 'palli-palli' ('quickly-quickly'), "The first Korean word learnt by local and imported workers" (interview notes), in everything conflicted with other local cultural norms. This constantly irritated the Korean management. Furthermore, in the MNC management explained that: "The communication style was via 'satu arah', which is 'one direction' or 'one way' in its flow" (interview notes).

\section{Employee Rewards}

Generally, compensation packages were drawn up according to legal provisions. The Employment Act (1955) is enforced by the Labour Department and stipulates basic terms and conditions, including benefits, pertaining to employment. Basic wages were paid according to agreed rates. In general, there was an absence of performance-based pay, with the exception of employees in sales divisions who did earn commission along with basic pay. In reality two types of compensation system were applied. First, managerial and professional employees were paid a fixed monthly salary based on the individual's job category and grade level. Second, general and production workers were paid daily-rated wages. This system was commonly used by manufacturing companies, including MNCs, in Malaysia. Pay increments were yearly and based on employee's salary scales. Besides the basic salary, workers also received other payments, for example, allowances for overtime, shifts, meals and transport.

Fringe benefits schemes were in line with legal regulations. Provisions were made for paid holidays and various type of leave (annual, sick, maternity, hospitalisation and pilgrimage for Muslims). None of the companies had their own pension or old-age social security scheme. This was partly due to the legal requirements of the local Employees' Provident Fund scheme for old-age social security. This scheme had rates of contribution, as a percentage of the individual's wages, of 10 percent for employees and 12 percent for employers. There was also the Social Security Organisation Scheme for social insurance covering contingencies arising out of industrial injury or death. The legal obligation was for employees whose wages did not exceed RM2,000 per month to contribute to two schemes under the Social Security Organisation Scheme, i.e. the Employment Injury Insurance and Invalidity Pension schemes.

Interestingly, the MNC was busy benchmarking its compensation packages. This was because it was felt by management that: "We are lagging behind in terms of the perceived better payers, the Japanese, and especially American, firms" (interview notes). This was especially as: "These sorts of firm were our direct competitors for people in a tight local labour market" (interview notes). The MNC also "...provided all staff with longer lunch breaks to incorporate Friday prayers" (interview notes) and "We had to move from the locally unpopular six-day operation pattern of most of its 
other international plants, to five and half days and now we face pressure to drop again, to five day operations" (interview notes).

A varied array of compensation and benefits was provided. This included 'congratulatory' (first marriage, birth of child, children's marriage), 'compassionate' (family deaths) and 'calamity' (fire and flood) days off, and payments for birthdays, funerals (employee and relatives) and long service, while subsidized meals and accommodation was also offered.

\section{Discussion and Implications}

These results in the four key practice areas of the management of HR throw light on our issues concerning people management in Malaysian companies in terms of the HRM function and the influence of MNCs. We have more evidence from the MNC than LOCs on the first issue, a situation that is reversed for the second issue.

\section{HRM Function}

First, the HRM function and the idea of the emergence of an HRM over a PM approach to the management of people. This trend was weak. The LOCs had not shifted far from the scientific management oriented approach of 'Fordism' and 'Taylorism' (with mass production for mass markets) towards workers. While the country has economically and socially developed, change in the management of HR has lagged behind. In the main people management is still characterized as more like PM than HRM. For instance, there was to a certain extent a low commitment to HR by top management, who showed little, if any, long-term commitment to HR issues. Management tended to treat staff as variable, rather than fixed, assets and HR issues of secondary importance as priorities centred upon financial control and profit maximization of the operations. In this instance, Yamaguchi (1999) asserts that it is the culture (national) rather than the worker-type (organisational type) factor that has a more powerful effect on various job-related orientations, such as a human relations orientation, including the management of HR.

The LOCs did not actually have any designated HR Managers. HRM functions were the responsibility of General Managers or Managing Directors. In reality, however, designated administrative executives were responsible for day-to-day management of HR. In general, the HRM function was seen as still dealing with the routine maintenance and regulation of employees. There was no effort by management to monitor the impact of HR strategy on the business results of companies. Little or no attention was given to strategic HR planning. Consequently, there was an absence of strategic HRM. Firm size may, obviously, be an important influence, although the largest companies included did have over 300 employees.

In all the companies there appeared to be the domination of an autocratic type of management, with a top-down communication flow. Management lacked awareness that more bottom-up communication could motivate the workforce and increase their understanding of their role in improving quality and productivity.

The MNC, in contrast, had a very well developed HRM function and: "This was generously resourced and staffed" (interview notes). The HR team was headed by a General Manager (Korean) with a Malay HR Manager, and a large compliment of spe- 
cialist HR Officers and Assistants (Malay) below that. There was a recent 'Global HR' strategy emanating from the Korean headquarters. This set out the parameters of the function and linked to all its world-wide operations and all of which could access each other's HR systems on-line. However, there was local variability in HR practice. Another aspect of trying to forge a more consistent and common HRM across the MNC was the use of inter-subsidiary meetings. There were trips and conferences for members of the senior HR team. These were both back to Korea and regionally in Asia, to meet other HR staff and share and discuss HR practices.

The senior HR managers did perceive the strategic importance of HR. This could be seen in HRM areas such as employee resourcing and employee development, both of which required not reactive, ad hoc reactions, but rather proactive, long term decisions and actions to manage them suitably. This trickled down as even lower level HR staff argued for the strategic importance of the HR function, although the reality was sometimes more the continuation of a traditional, PM approach of implementing decisions, administration, etc.

The findings of our paper are an indication that HRM has a long way to go before becoming an agent of change among LOCs. Top management has yet to accept that HR managers could play a role in facilitating change, to locate and implement the critical forces of change necessary for organisational success. HR are becoming a crucial and differentiating factor for companies; thus managers have to understand the process that results in the creation of competitive human capital. HR managers are expected to plan strategically, so that they will build, develop and retain employees in a similar way that top management directs the company to accomplish its goals.

Thus, it is pertinent that one challenge facing Malaysian companies is the level of innovation top management demonstrates in integrating HRM in meeting organisational needs. This will in turn provide the opportunity for organisational competitiveness in attracting premium human capital. Essentially, employers must pay special attention to the progression of their employees, especially in terms of upgrading skills. For instance, if LOCs, especially small and medium enterprises, are to be included as original equipment manufacturers or component suppliers for MNCs their workforce must possess the necessary skills to obtain contracts. Interestingly, the MNC case study company was itself a contract supplier to other MNCs. For example, it manufactured finished products under several brand names and also supplied the product's key parts and electronics to other manufacturers, including its direct competitors. It was argued that: "This production for other multinationals was pushing the company to develop its staff, such as with Six Sigma programmes. This was due to the need to meet the demands of key customers, such as GE of America, to comply with its standards. This was leading to the upgrading of production and quality to maintain this contract" (interview notes). This was critical to the Malaysian factory as the MNC head quarters was transferring the last of its Korean microwave assembly lines, which had previously dealt with the largest, most sophisticated and high quality and cost and most value-added models (under another brand) to Malaysia.

While training can be costly, in the long run it can prove critical to company success. The term training 'cost' should be replaced by 'investment', implying a long-term view of its outcomes (see Rowley 2003). By and large, the success of many companies, 
such as the Japanese, is based on belief that a high standard of performance is dependent on highly trained HR. Brown and Read (1984) perceived that the training and development policies of Japanese companies were continuously formulated and correlated within the same framework as the business plans. Many agree that employee development is crucial for career advancement (Delery/Doty 1996; Flanagan/ Deshpande 1996; Veiga/Pfeffer 1999). It is apparent that Malaysian domestic companies need to put more emphasis on employee development. However, these companies often lack the resources to engage fully in training, and thus the ability to upgrade themselves technologically depends significantly on the subsidized programmes provided through the government's HRDC.

\section{Influence of $M N C s$}

This paper also sought to understand whether LOCs were influenced by the HRM practices of MNCs operating in Malaysia. In general, respondents in LOCs agreed that the HR practices of MNCs were of a 'higher' standard compared to their own. These people were of the opinion that it would be costly for them to adopt practices which are common in the MNCs. Thus, we could deduce, while there was benchmarking of a sorts against the HRM practices of MNCs by local managers, this did not then develop into implementing the same practices in their firms. Rather, MNCs were seen as in a 'different league'. It was other local firms that were of much more interest and concern.

Staff at the MNC concurred with this situation. As was commonly argued that: "We rarely have any HR dealings with indigenous companies, but rather with the subsidiaries of other multinationals" (interview notes). Indeed, in terms of MNCs as carriers of HRM change, there are constraints. There were few direct contacts between MNCs and local firms, either as suppliers of labour (taken from other areas/countries or MNCs) or products (taken from home country or other MNC subsidiaries). Few MNC staff left to go to work for domestic firms. Rather, they either returned to their home country if on contracts, or went to work for one of the other MNCs, or went back to their villages.

Interestingly, the opposite trend - the MNC taking on-board LOC HRM - could be felt in some instances. Thus, it was not just the MNC importing its own HRM, as we saw earlier in the employee resourcing policies. Rather, they were incorporating local HR practices, ie in the areas of employee rewards and the working work. While MNCs do influence indigenous HRM, this is mainly via impacts on other MNC operations, with less on LOCs.

There are a range of possible theoretical explanations for people management to change, or not, in Malaysia. First, the Institutional Theory perspective's idea that the take-up of HRM could be better explained by institutional legitimacy rather than by economic rationality finds some support but mainly between the subsidiaries of MNCs. The lack of uptake of key aspects of the HRM model in LOCs seems to militate against Resource-Based Theory. The Organisational Learning Theory argument is also related to the economic development process. In the early stages of economic emergence firms can take an imitation strategy with reverse engineering (Kim 1997). In this, firms heavily engage in 'exploitation' at the exclusion of 'exploration' (March 
1991; Bae/Kim 2004). However, as economies advance, firms may have to engage more in the exploration of new possibilities through HRs with creativity and variations. These changes encourage firms to take different approaches to HRs. We can see the beginnings of such ideas. However, crossing this rubicon between types of innovation will face Malaysian firms soon. A Strategic Choice view argues that as Malaysian firms upgrade business strategies, then a commensurate shift in HRM is needed. Again, the uptake of a 'classic' HRM model in domestic companies seems weak, let alone the development of strategy and choice in HRM. In a Transaction Cost Theory perspective there are costs associated with HR arrangements. For instance, firms may have inflexible labour markets, and hence keep long-term employment, regardless of bureaucratic costs incurred by hierarchical arrangements due to issues such as difficulties in monitoring and securing compliance from workers, in turn impacting on the development and transfer of flexible type HRM. There is some evidence of this in Malaysia.

Finally, some issues in this research need to be noted as limitations to our findings. One issue stems from the HRM concept itself. This has Western, AngloAmerican roots and it may have less relevance in other contexts, such as Asian locales. Of course there are the obvious issues of using case studies. Yet, more 'representative' surveys also face the common problem of response and meaning. Another issue was some reluctance by companies to participate in the research. However, the unwillingness of local organisations to cooperate with academic researchers is commonplace. Even official bodies suffer from this, e.g. the National Malay Chamber of Commerce, Malaysia encountered similar problems in getting cooperation from local companies for a census-type study in 2001.

Another issue is that the companies are sectorally biased - all in manufacturing, not services. Neither are the firms that large. Perhaps these characteristics all weaken the prospects of finding people management that is more like HRM than PM. On the other hand, it is possible there is a bias in our cases towards those more likely to have HRM than PM as firms were self-selecting in giving research access and located in the most advanced and developed part of the country in close proximity to most of the MNCs subsidiaries. These may be the very firms with the most to 'show' and the 'best' practices (i.e. with HRM). Of course, firms may simply be too busy in general, too busy with their 'excellent HRM', or feel they have noting to learn because they already have HRM.

Also, there was only a single MNC involved. Nevertheless, these issues and limitations need to be balanced against the following. First, the MNC in question was seen by many decision makers and actors as the leading firm and it was even stated by one expert that: "When we speak of Korean firms in Malaysia, it is actually only this company we think off and are talking about, it is by far the most important and dominant in the country" (interview notes). Second, it allowed for the control of effects such as organisational culture and other attributes.

Another limitation is that all the companies were from industrial estates within the vicinity of the Kuala Lumpur region, not nationally, as it was not feasible within limited resources and time constraints, to conduct a nationwide study. Furthermore, the research is based on just one country. The findings of the study could be tested in 
other contexts. Researchers could possibly conduct a comparative study to gauge the transformation of HRM in domestic companies within the Asian region.

\section{Conclusion}

Our paper has analysed the management of HR in companies in Malaysia. The convergence perspective's prediction of coalescence around a 'one best way' HRM has not been borne out. Firms may be converging within countries in categories (i.e. domestic firms with other domestic firms, MNC operations with other MNC operations), this is less across categories (i.e. domestic firms with MNC operations) within countries.

In the final analysis if we were to assess what sort of approach towards the management of people Malaysian indigenous domestic firms have adopted, the answer would be: more like traditional PM than a classic HRM concept. Companies have operated mainly on a low-cost strategy and have little concern for employee development. In the past this matched the economic development model of the time. However, times have changed. Other Asian economies (China, Vietnam) offer lower labour costs. Malaysia needs to compete in a different manner. This can be by offering better, skilled workforce and a stable and benign operating environment, in turn require changes in management and long term views, as in HRM. The government has emphasized the need for companies to properly utilize HR. Nonetheless, companies appear not to be enthusiastic. To a certain extent employers perceive HR as the first matter to deal with when restructuring or downsizing, thus neglecting employee development. Interestingly, the MNC had foreseen some of this and was in the process of segmenting it production between the low cost/simplest items (moving from Malaysia to sister plants in China, Thailand) and high cost/quality and sophisticated products (moving from Korea to Malaysia).

Looking to the future, the greater development and emergence of the HRM profession in Malaysia may act as a medium or carrier of ideas about HRM. In relation to this, Björkman and $\mathrm{Lu}(1999)$ assert that networking provides good opportunities for benchmarking with other organisations. Thus, one of the ways in which the advance of HRM in domestic firms may take place is through the interaction of management in semi-formal networks, such as those organized by the National Chamber of Commerce and other business-enhancement organisations. For example, the interaction of management and HR staff of domestic companies and their counterparts from foreign companies and MNCs may influence the uptake of HRM policies and practices of domestic companies. As Rowley and Abdul-Rahman(2008b) note, some Malaysian firms have begun to focus significant attention towards HRM, innovation and productivity as managers realize that people are capable of generating competitive advantages and become more aware of the integral role of HRM in organisations.

Also, managers could be made aware that HR systems can substantially influence the performance of firms when aligned with appropriate buisness strategies (Youndt et. al. 1996). Studies have indicated that different HRM strategies produce varied effects on organisational performance. Lieberman et al. (1990) observed that Japanese auto producers achieved higher productivity after they had adopted 'better' HRM practices. Kelly and London (1989) stressed the crucial role played by HRM in en- 
hancing competitiveness in Taiwan, Korea, Singapore and Thailand. In addition, the adoption of different HRM methods produced different effects on organisational performance (Bamberger et al. 1989; Terpstra/Rozell 1993). Research also shows that various forms of work arrangements may increase employees' commitment towards organisations, consequently minimizing absenteeism and labour turnover (Erza/Deckman 1996; Kirrane 1994).

Indeed, the government has recognized the importance of developing human capital. This is indicated in its document The Way Forward (Vision 2020) (undated) utlining objective of developing Malaysia into an industrialized country by 2020 . In this the Economic Planning Unit affirms that Malaysia should not be developed only in the economic sense, but also other dimensions: national unity and social cohesion, social justice, political stability, system of government, quality of life, social and spiritual values, national pride and confidence.

In order for Malaysian firms to compete they need to examine their management of HR. HRM's efficacy depends on its fit with the firm's stage of development. As the firm grows and develops, HRM programmes, practices and procedures must transform and develop to meet the company's growing needs.

Malaysian firms, both indigenous and local MNC plants, face some tough choices. As Malaysia's labour costs rise, along with is relatively small workforce, the fulcrum of cheap and available labour is shifting to other countries, such as China and Vietnam. In this context, how will Malaysian firms remain competitive? Upgrading $\mathrm{HR}$, as via HRM, is one possible route out of this impasse.

\section{References}

Abdullah, Wan Aziz Wan (1994): Transnational Corporations and Human Resource Development. Some Evidence from the Malaysian Manufacturing Industries. In: Personnel Review, 23(5): 4-20.

Adnan, M.A./Ali, A. (1990): Technological Acquisition and Absorption via Multinational Companies: the Malaysian Experience. In: Jurnal Ekonomi Malaysia (21-22): 151-171.

Ali, A. (1992): Malaysia's Industrialization: The Quest for Technology. Singapore: Oxford University Press.

Alhabshi, S.O./Ghazali, A.H. (1994): Islamic values and management. Kuala Lumpur: Institute of Islamic Understanding Malaysia.

Arthur, J. (1992): The Link Between Business Strategy and Industrial Relations Systems in American Steel Minimills. In: Industrial and Labor Relations Review, 45: 488-506.

Asma, A. (2001): Influence of Ethnic Values at the Malaysian Workplace. In: Asma, A./Low, A.H.M. (eds.): Understanding the Malaysian Workforce: Guidelines for Managers. Kuala Lumpur: Malaysian Institute of Management: 1-20.

Ayudurai, D./Yahaya, S.R./Zainuddin, S. (2002): Malaysia. In: Zanko, M. (ed.): The Handbook of HRM Policies and Practices. In: Asia-Pacific Economies, 1, Cheltenham: Edward Egar.

Bae, J./Kim, O. (2004): Strategic 'HRM and Innovative Performance: Exploratory Versus Exploitative Innovation Compared. In: Paper Presented to Annual Korean Academy of Management Conference.

Bae, J./Rowley, C. (2001): The Impact of Globalisation on HRM: The Case of South Korea. In: Journal of World Business, 36(4): 402-28.

Bamber, P./Bacharach, S./Dyer, L. (1989): HRM and Organizational Effectiveness: High Technology Startup Firms in Israel. In: Human Resource Management, 28(3): 349-361.

Barney, J.B. (1991): Firm Resources and Sustained Competitive Advantage. In: Journal of Management, 17(1): 99-120. 
Becker, B./Gerhart, B. (1996): The Impact of HRM on Organizational Performance: Progress and Prospects. In: Academy of Management Journal, 39(4): 779-801.

Beekum. R./Badawi, J. (1999) Leadership: An Islamic perspective. Beltsville: Amana Publications.

Beer, M./Spector, B./Lawrence, P.R./Quin Mills, D./Walton, R.E. (1984): Managing Human Assets. New York: Macmillan.

Bhopal, M./Rowley, C. (2002): The State in Employment: The Case of Malaysian Electronics. In: International Journal of Human Resource Management, 13(8): 1166-1185.

Bhopal, M./Todd, P. (2000): Multinational Corporations and Trade Union Development in Malaysia. In: Rowley, C./Benson, J. (eds.): Globalisation and Labour in the Asia Pacific Region. London: Frank Cass: 193-213.

Bird, A./Beechler, S. (1994): Links Between Business Strategy and HRM Strategy in U.S.-Based Japanese Subsidiaries: An Empirical Investigation. In: Journal of International Business Studies, 26: 23-46.

Björkman, I./Lu, Y. (1999): Institutionalization and Bargaining Power Explanations of HRM Practices in Chinese-Western Joint Ventures. In: Organisation Studies, 22: 491-512.

Bratton, J./Gold, T. (1994): Human Resource Management: Theory and Practice. London: Macmillan.

Brewester, C. (1993): Developing a 'European' Model of HRM. In: International Journal of Human Resource Management, 4(4): 765-785.

Brown, G./Read, A.R. (1984): Personnel and Training Policies - Some Lessons for Western Companies. In: Long Range Planning, 17(2): 48-57.

Burton, J. (2006): Palm Oil: Malaysia Plans World's Biggest Listed Producer. In: Financial Times, 24th November, 23.

Darwish, A.Y. (2000): Organizational commitment as a mediator of the relationship between Islamic work ethic and attitudes toward organizational change. In: Human Relations, 45 (4): 513-37.

Delery, J.E./Doty, D.H. (1996): Modes of Theorizing in Strategic HRM Tests of Universalistic, Contingency, and Configurational Performance Predictions. In: Academy of Management Journal, 39: 802-35.

Economist, The (2005): The Malay Way Of Business Change. In: 20th August, 54

Eisenhardt, K. (1989): Building Theories from Case Studies Research. In: Academy of Management Review, 14(4): 532-550.

Erza, M./Deckman, M. (1996): Balancing Work and Family Responsibilities: Flextime and Child-care in the Federal Government. In: Public Administration Review, 56(2): 174-176.

Farh, J./Dobbins, G.H./Cheng, B.S. (1991): Cultural relativity in action: A comparison of self-ratings made by Chinese and US workers. In: Personnel Psychology, 44: 129-67.

Flanagan, D. J./Deshpande, S.P. (1996): Top Management's Perceptions of Changes in HRM Practices After Union Elections in Small Firms: Implications for Building Competitive Advantage. In: Journal of Small Business Management, 34(4): 23-35.

Fombrun, C./Tichy, N.M./Devanna, M.A. (1984): Strategic Human Resource Management. New York: Wiley.

Hofstede, G. (1998): Think Locally, Act Globally: Cultural Constraints in Personnel Management. In: Management International Review, 38(2), Special Issue: 7-26.

Hofstede, G. (1991): Culture's consequences: Software of the mind. London: McGraw-Hill.

Hooi, Lai Wan (2002): The Impact of Japanese Promotion Practices on Malaysian Enterprises. In: Asia Pacific Business Review, 9(1): 21-38.

International Labour Organisation (2007b): Labour and Social Trends in ASEAN 2007: Integration, Challenges and Opportunities.

Jackson, S.E./Schuler, R.S. (2000): Managing Human Resources, A Partnership Perspective. London: South-Western College Publishing.

Kim, L. (1997): Imitation to Innovation: The Dynamics of Korea's Technological Learning. Boston, MA: Harvard Business School Press.

Kelly, B./London, M. (1989): The Four Little Dragons. New York, NY: Simon \& Schuster.

Kerr, C./Dunlop, J./Harbison, F./Myers, C. (1959): Industrialism and Industrial Man. London: Heinemann.

Kirrane, E.D. (1994): Wanted: Flexible Work Arrangements. In: Association Management, 46(11): 38. 
Kostova, T. (1999): Transnational Transfer of Strategic Organizational Practices: A Contextual Perspective. In: Academy of Management Review, 24(2): 403-28.

Kuruvila, S. (1996): Linkages Between Industrialization Strategy and Industrial Relations/HRM Practices: Singapore, Malaysia, The Philippines and Indonesia. In: Industrial and Labor Relations Review, 49(4): 635-57.

Lepak, D.P./Snell, S.A. (1999): The Human Resource Architecture: Toward a Theory of Human Capital Allocation and Development. In: Academy of Management Review, 24(1): 31-48.

Legge, K. (1989): HRM: A Critical Analysis. In: Storey, J. (ed.): New Perspectives on Human Resource Management. London: Routledge.

Lieberman, M./Lau, L./Williams, M. (1990): Firm-Level Productivity and Management Influence: A Comparison of US and Japanese Automobile Producers. In: Management Science, 36: 1193-1216.

MacDuffie, J.P. (1995): Human Resource Bundles and Manufacturing Performance: Organizational Logic and Flexible Production Systems in the World Auto Industry. In: Industrial and Labor Relations Review, 48: 197-221.

Mansor, N./Ali, M. (1998): An exploratory study of organizational flexibility in Malaysia: A research note. In: International Journal of Human Resource Management, 9 (3):506-15.

March, J.G. (1991): Exploration and Exploitation in Organizational Learning. In: Organization Science, 2: 71-87.

McKinley, W./Sanchez, C.M./Schick, A.G. (1995): Organizational Downsizing: Constraining, Cloning, Learning. In: Academy of Management Executive, 9(3): 32-44.

Mellahi, K./Wood, G. (2004): HRM in Malaysia. In: Budhwar, P. (ed.): Managing Human Resources in Asia-Pacific. London: Routledge

Meyer, J./Rowan, B. (1977): Institutionalized Organizations: Formal Structures, Myth and Ceremony. In: American Journal of Sociology, 83(2): 340-63.

Miles, R.E./Snow, C.C. (1984): Designing Strategic Human Resources Systems. In: Organizational Dynamics, 13: 36-52.

Noordin, F./Williams, T./Zimmer, C. (2002): Career commitment in collectivist and individualist cultures: A comparative study. In: International Journal of Human Resource Management, 13(1): 3554.

Pfeffer, J. (1994): Competitive Advantage Through People. Boston, MA: Harvard Business School Press.

Pfeffer, J. (1998): The Human Equation: Building Profits By Putting People First. Boston, MA: Harvard Business School Press

Pieper, R. (1990): Human Resource Management: An International Comparison. Berlin: Walter de Gruyter.

Poole, M. (1990): HRM in an International Perspective. In: International Journal of Human Resource Management, 1: 1-15.

Porter, M.E. (1980): Competitive Strategy: Techniques for Analyzing Industries and Competitors. New York: Free Press.

Raduan, Che Rose (2002): Japanese-style Management Abroad: the Case of Malaysian Subsidiaries. Kuala Lumpur: Prentice Hall/ Pearson Education.

Ragayah Haji Mat Zin/Lee Hwok Aun/Saaidah Abdul-Rahman (2002): Social Protection in Malaysia. In: Adam, E./von Hauff, M./John, M. (eds.): Social Protection in Southeast and East Asia. Singapore: Friedrich Ebert Stiftung: 119-170.

Rasiah, R. (1988): The Semiconductor Industry in Penang: Implications for the New International Division of Labour Theories. In: Journal of Contemporary Asia, 18: 1.

Rowland, K.M./Summers, S.L. (1981): Human Resource Planning: A Second Look. In: Personnel Administration, 26: 73-80.

Rowley, C. (2003): The Management of People: HRM in Context. London: Spiro Press.

Rowley, C./Bae, J. (2004): HRM in South Korea After the Asian Financial Crisis: Emerging Patterns from the Labyrinth. In: International Studies of Management and Organization, 31(1): 52-82.

Rowley, C./Benson, J. (2002): Convergence and Divergence in Asian HRM. In: California Management Review, 44(3): 90-109.

Rowley, C./Benson, J. (2004): The Management of Human Resources in the Asia Pacific Region: Convergence Questioned. London: Frank Cass. 
Rowley, C./Bhopal, M. (2002): The State in Employment: The Case of Malaysian Electronics. In: International Journal of Human Resource Management, 13(8): 1166-1185.

Rowley, C./Bhopal, M. (2005): The Role of Ethnicity in Employee Relations. In: Asia Pacific Journal of Human Resources, 43(3): 308-331.

Rowley, C./Bhopal, M. (2006): The Ethnic Factor in State-Labour Relations. In: Capital and Class, 88: 87-116.

Rowley, C./Abdul-Rahman, S. (2008a): Introduction. In: Rowley, C./Abdul-Rahman, S. (eds.): The Changing Face of Management in South East Asia. Routledge: 1-27.

Rowley, C./Abdul-Rahman, S. (2008b): The Changing Face of Management in Malaysia. In: Rowley, C./ Abdul-Rahman, S. (eds.): The Changing Face of Management in South East Asia. Routledge: 59-96.

Osenzweig, P.M./Hohria, N. (1994): Influences on HRM Practices in Multinational Corporations. In: Journal of International Business Studies, 25(2): 229-252.

Schuler, R. (1989): Strategic HRM. In: Human Relations, 42: 157-184.

Shin Y.K. (1999): HRM in Korean Firms and its Future Outlook. In: Seoul Journal of Business, 5(1/2): 134.

Smith, W. (2000): Management in Malaysia. In: Warner, M. (ed.): Regional Encyclopedia of Business and Management: Management in Asia Pacific. London: Thomson Business Press: 244-259.

Smith, W. (2003): Culture and Management in Malaysia. In: Warner, M. (ed.): Culture and Management in Asia. London: Routledge Curzon: 115-134.

Smith, W./Abdullah, A (2004): The Impact of the Asian Crisis on HRM in Malaysia. In: Asia Pacific Business Review, 10(3/4): 402-21.

Snell, S.A./Youndt, M.A./Wright, P.M. (1996): Establishing a Framework for Research in Strategic HRM: Merging Resource Theory and Organizational Learning. In: Ferris, G.R. (ed.): Research in Personnel and Human Resources Management (14). Greenwich and London: JAI Press: 61-90.

Storey, J. (1992): Developments in the Management of Human Resources. Oxford: Blackwell.

Storey, J./Sisson, K. (1993): Managing Human Resources and Industrial Relations. Buckingham: Open University Press.

Taib, A./Ismail, M.Y. (1982): The Social Structure. In: Fisk, E.K./Osman-Rani, H. (eds.): The Political Economy of Malaysia. Kuala Lumpur: Oxford University Press.

Tayeb, M. (1998): Transfer of HRM Practices Across Cultures: An American company in Scotland. In: International Journal of Human Resource Management, 9(2): 332-58.

Terpstra, D.E./Rozell, E.J. (1993): The Relationship of Staffing Practices to Organizational Level Measures of Performance. In: Personnel Psychology, 46: 27-48.

Thome, K./McAuley, I. (1992): Crusaders of the Rising Sun: A Study of Japanese Managers in Asia. Singapore: Longman.

Veiga, J.F./Pfeffer, J. (1999): Putting People First for Organizational Success. In: The Academy of Management Executive, 13(2): 37.

Wad, P. (2002): How Do TNCs Interact with Domestic Trade Unions in Malaysia?. In: SchaumburgMüller, H./Schmidt, J. D. (eds.): The Global Positioning of Firms and Local Responses in Developing Countries. Development Research Series, Occasional Papers 3, RCDIR, Aalborg University.

Walton, R.E./Lawrence, P.R. (1985): Human Resource Management: Trends and Challenges, Boston. MA: Harvard Business School Press.

Williamson, O.E. (1975): Markets and hierarchies: Analysis and antitrust implications. New York: The Free Press.

Wolfe, D./Arnold, B. (1994): HRM in Malaysia: A Comparison Between American and Japanese Approaches. In: Journal of Asian Business, 10(4): 80-103.

Yamaguchi, I. (1999): Effects of National Culture and Organizational Types of Workers on the JobRelated Orientations of Japanese, US and Australian Employees. In: Leadership \& Organization Development Journal, 20(1): 36-45.

Yin, R. (1989): Case Study Research: Design and Methods. Chicago, IL: Dryden.

Youndt, M.A./Snell, S.A./Dean, J.W. Jr. (1996): HRM, Manufacturing Strategy, and Firm Performance. In: Academy of Management Journal, 39(4): 836-66. 